\title{
Zircon U-Pb ages of granitoid apophyses in the western part of the Kłodzko-Złoty Stok Granite Pluton (SW Poland)
}

\author{
Stanisław Zbigniew MIKULSKI ${ }^{1, *}$ and lan Stuart WILLIAMS ${ }^{2}$ \\ 1 Polish Geological Institute - National Research Institute, Rakowiecka 4, 00-975 Warszawa, Poland \\ 2 Research School of Earth Sciences, Australian National University, ACT 0200, Canberra, Australia
}

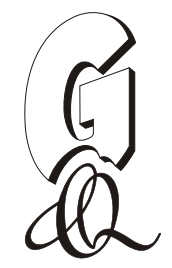

Mikulski, S.Z., Williams, I.S., 2014. Zircon U-Pb ages of granitoid apophyses in the western part of the Kłodzko-Złoty Stok Granite Pluton (SW Poland). Geological Quarterly, 58 (2): 251-262, doi: 10.7306/gq.1141

\begin{abstract}
Granitoids from the Graniec-Bardo and Myszak apophyses of the Kłodzko-Złoty Stok (KZS) Granite Pluton that intrude the Upper Paleozoic flysch of the Bardo Unit have zircon U-Pb ages, measured by SHRIMP, of 341.6 $\pm 2.8 \mathrm{Ma}$ and $341.4 \pm$ $2.2 \mathrm{Ma}$, respectively. These results augment our previous dating that recorded a short period of Middle Mississippian (Visean) hypabyssal magmatism that produced a variety of KZS igneous rocks of different compositions between ca. 341 and $331 \mathrm{Ma}$. The Graniec-Bardo and Myszak apophyses belong to the earliest stage of the pluton emplacement. Geochemical and petrographic studies of the dated samples indicate that they are biotite- and hornblende-rich tonalite and syenogabbro of diverse composition and typical of rocks originating from hybrid magmas formed in the geotectonic transition from an early stage collisional granitoid emplacement to its fast orogenic uplift. The polymetallic auriferous ore mineralisation of contact metasomatic type found in intimate contact with the Graniec-Bardo apophysis near Bardo Śląskie may also be of Visean age.
\end{abstract}

Key words: Variscan granitoids, apophyses, zircon, SHRIMP geochronology, Sudetes.

\section{INTRODUCTION}

In this paper, we present new geochronological data for igneous rocks collected from the western parts of the Kłodzko-Złoty Stok (KZS) Granite Pluton. These results supplement SHRIMP (Sensitive high-resolution ion microprobe) zircon U-Pb dating from the KZS that we have already published (Mikulski et al., 2013). That dating showed that igneous zircon recorded hypabyssal magmatism that produced various granitoids and lamprophyres that were emplaced from ca. 341 to $331 \mathrm{Ma}$. Until now, the earliest recorded phases of magmatism in the region were represented by the quartz monzodiorite from Żelazno (340.2 $\pm 2.5 \mathrm{Ma}$; Z248 - see sample location on Fig. 1), the hornblende monzonite from Droszków (339.5 $\pm 2.8 \mathrm{Ma}$; D148), and the biotite-hornblende granodiorite from Chwalisław $(336.7 \pm 2.3 \mathrm{Ma}$; M10). Given the analytical uncertainties, however, these age estimates are mutually indistinguishable. Slightly later magmatism was represented by the tonalite from Ptasznik Hill $(331.5 \pm 2.6 \mathrm{Ma}$; P9) and the crosscutting spessartite dyke from Chwalisław (M11), 333.1 $\pm 3.1 \mathrm{Ma}$ (Mikulski et al., 2013). These results together with geochemical data allowed us to assign the KZS granitoids to the older group

\footnotetext{
* Corresponding author, e-mail: stanislaw.mikulski@pgi.gov.pl
}

Received: October 24, 2013; accepted: December 30, 2013; first published online: December 31, 2013 of Variscan syn-collisional granitoids emplaced in the Sudetic Block in the Carboniferous (Tournaisian-Visean), ca. $40 \mathrm{Ma}$ earlier than had previously been proposed based on K-Ar dating (Depciuch, 1972).

\section{GEOLOGICAL SETTING OF THE KŁODZKO-ZŁOTY STOK GRANITE PLUTON}

The Kłodzko-Złoty Stok (KZS) Granite Pluton is exposed in the eastern part of the Sudetic Block which constitutes the eastern prolongation of the Saxothuringian Zone within the Central European Variscides on the northern margin of the Bohemian Massif (Franke and Żelaźniewicz, 2000). To the north, the KZS pluton is separated from the Fore-Sudetic Block by the Marginal Sudetic Fault. The KZS is bordered on the NW and W by the Bardo Structure, consisting mainly of allochthonous and minor autochthonous successions of altered Devonian to Carboniferous (Mississippian) sedimentary rocks (Oberc, 1972; Turnau et al., 2002) and by the Kłodzko Metamorphic Unit. The main deformation in the area occurred at the turn of the Middle to Late Devonian, followed shortly thereafter by regional uplift and a succession of tectonic activities in the Carboniferous (Mazur et al., 2006). The KZS is bounded to the SE by the NE part of the Orlica-Śnieżnik Dome. Along the eastern margin of the pluton is the Złoty Stok-Skrzynka Shear Zone, a belt of blastomylonites, mylonites, cataclasites, gneisses and schists, formed during Variscan deformation (Cymerman, 1996). The roof of the KZS pluton is preserved as irregularly distributed rel- 
ics of Early Paleozoic volcanic and sedimentary rocks related to the Lądek-Śnieżnik Metamorphic Complex (Wojciechowska, 1975). The sedimentary rocks enclose mafic and felsic intercalations. They are regionally metamorphosed to amphibolite facies, and then contact metamorphosed by the KZS intrusion.

The KZS pluton formed from l-type magma. It is composed mostly of high-K, metaluminous, biotite- and hornblende-rich granitoids of various compositions ranging from granodiorite to monzonite (Wierzchołowski, 1976; Lorenc, 1994; Bachliński and Bagiński, 2007; Mazur et al., 2007; Mikulski et al., 2013). The pluton contains rare xenoliths of metamorphic rocks and abundant mafic enclaves (Wierzchołowski, 1976). Mixing between mafic and felsic components was ubiquitous; layering and cumulate textures are visible locally, and interaction between the granitoids and xenoliths is common near the contacts between the granitoids and their host rocks (Lorenc, 1994). SHRIMP zircon U-Pb dating of igneous rocks from the KZS indicates that the granitoids and lamprophyres were intruded in the Carboniferous (Middle Mississippian-Visean) from ca. 341 to $331 \mathrm{Ma}$ (Mikulski et al., 2013). The magmatic episode lasted ca. $10 \mathrm{Ma}$ and was concurrent with orogenic uplift and cooling. Subsequent magmatic activity formed dykes of melanocratic and leucocratic rocks, and was followed by hydrothermal activity responsible for quartz vein formation (Wierzchołowski, 1977; 2003; Cwojdziński, 1981; Awdankiewicz, 2007; Awdankiewicz et al., 2010). The KZS contact-metasomatic aureole is composed mainly of garnet-cordierite hornfels, hercynite-corundum hornfels, skarns, skarnoids, marbles and various pyroxene-plagioclase rocks (Wierzchołowski, 1976). Strong contact metasomatic processes at the same time were responsible for the local metasomatic mineralisation (scheelite-titanite) such as that at the Ptasznik prospect (Mikulski, 1999, 2000) and auriferous skarn mineralisation in the Złoty Stok Au-As deposit (Mikulski, 1996a, b, 1999; Mikulski and Speczik, 2008) or near Bardo Śląskie (Mikulski, 1998).

\section{METHODS AND MATERIALS}

Samples of quartz monzodiorite and monzonite for geochronological, petrographic and geochemical study were collected from two different places in the western parts of KZS Granite Pluton (Fig. 1). Major element contents of the samples were measured at the PGI-NRI by wavelength dispersive X-ray fluorescence techniques on glass beads, and minor and trace elements by WDS-XRF on powder pellets using a $P W-2400$ Philips and by digestion ICP-AES techniques. The conditions of the measurements for major oxides and trace elements were as follows: radiation - X-ray tube with $\mathrm{Rh}$ anode $(3 \mathrm{~kW})$; crystals LiF 200, PE, Ge, PX1; collimators - $0.15 \mathrm{~mm}, 0.30 \mathrm{~mm}$; detectors - scintillation counter, flow proportional counter $\left(\mathrm{Ar} / \mathrm{CH}_{4}\right)$ and Xe-sealed proportional counter. On the geochemical diagram, these analyses are plotted along with data from 48 whole-rock major element analyses compiled from Borkowska (1957), Pendias and Maciejewski (1959), Wierzchołowski (1976), Lorenc (1991) and Mikulski et al. (2013). The current data are listed in Table 1.

Mineral phases from two selected samples (KZ50 and KZ54) were analysed by XRD in the PGI-NRI laboratory using the X'Pert PW 3020 by Philips. The measurement conditions were: wavelength K-Alpha (1: 1.54056 A), K-Alpha (2: $1.54439 \mathrm{~A})$, K-Alpha2/K-Alpha (1), intensity ratio (0.5000) and

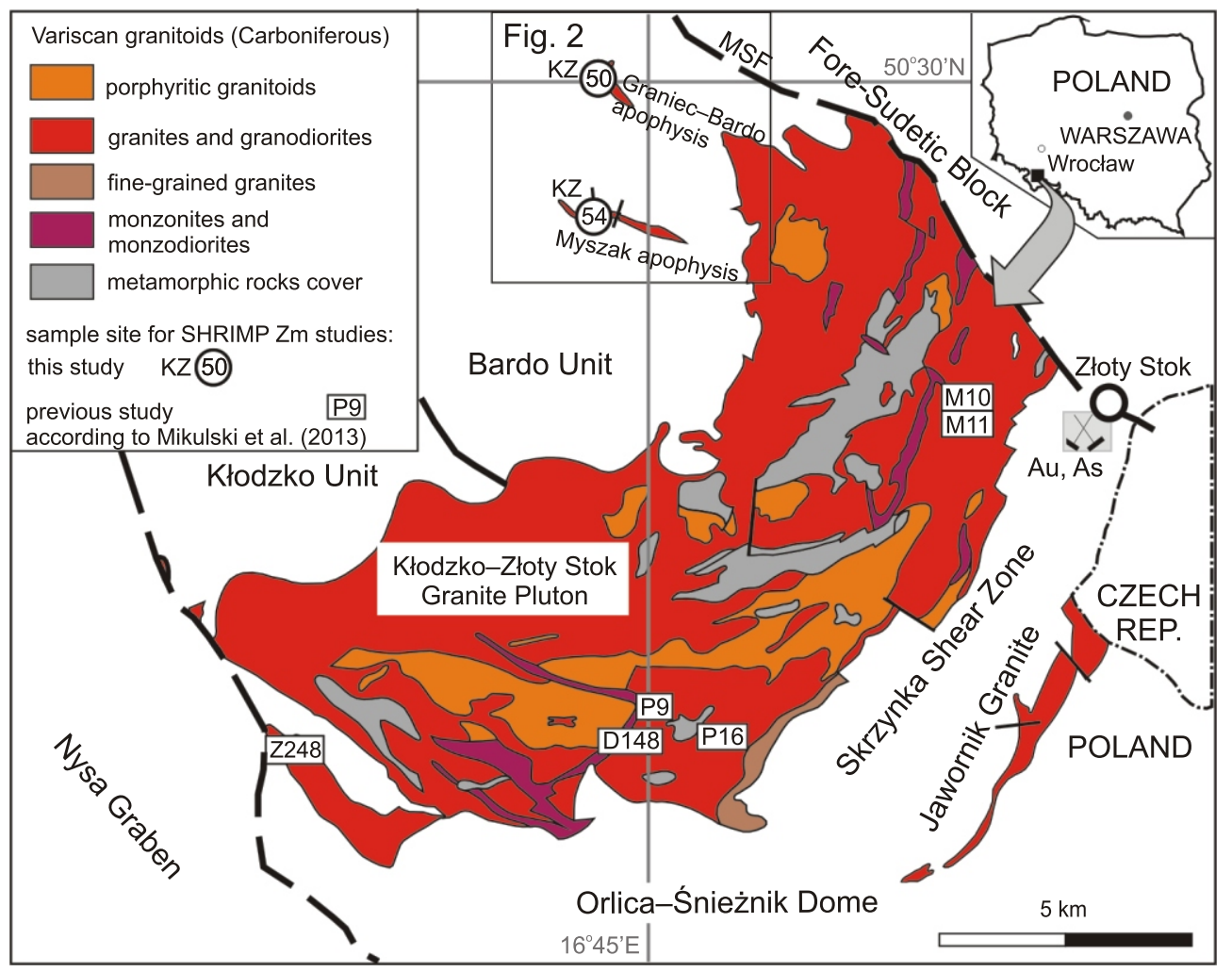

Fig. 1. Simplified geological map of the Kłodzko-Złoty Stok Granite Pluton and its environs (according to Sawicki, 1980, modified) with locations of the granite samples collected for SHRIMP zircon analysis 
Table 1

Chemical analyses of granitoid samples from apophyses located in the western part of the Kłodzko-Złoty Stok Granite Pluton

\begin{tabular}{|l|r|r|c|}
\hline \multirow{2}{*}{$\begin{array}{c}\text { Major oxides and element } \\
\text { [wt.\%] }\end{array}$} & \multicolumn{3}{|c|}{ Sample \# } \\
\cline { 2 - 4 } & $\mathrm{KZ50}$ & $\mathrm{KZ54}$ & $\mathrm{KZ54/B}$ \\
\hline $\mathrm{SiO}_{2}$ & 62.98 & 49.71 & 49.66 \\
\hline $\mathrm{TiO}_{2}$ & 0.59 & 0.87 & 0.88 \\
\hline $\mathrm{Al}_{2} \mathrm{O}_{3}$ & 16.55 & 20.51 & 21.03 \\
\hline $\mathrm{Fe}_{2} \mathrm{O}_{3}$ & 5.72 & 8.21 & 8.01 \\
\hline $\mathrm{MnO}$ & 0.1 & 0.15 & 0.14 \\
\hline $\mathrm{MgO}$ & 2.19 & 4.97 & 4.85 \\
\hline $\mathrm{CaO}$ & 3.6 & 9.57 & 9.28 \\
\hline $\mathrm{Na}_{2} \mathrm{O}$ & 3.36 & 2.96 & 2.97 \\
\hline $\mathrm{K}_{2} \mathrm{O}$ & 2.59 & 1.08 & 1.16 \\
\hline $\mathrm{P}_{2} \mathrm{O}_{5}$ & 0.11 & 0.13 & 0.15 \\
\hline $\mathrm{SO}$ & 0.08 & $<0.01$ & $<0.01$ \\
\hline $\mathrm{Cl}$ & 0.03 & 0.03 & 0.04 \\
\hline $\mathrm{F}$ & $<0.01$ & $<0.01$ & $<0.01$ \\
\hline $\mathrm{LOI}$ & 1.99 & 1.75 & 1.75 \\
\hline Total & 99.89 & 99.94 & 99.92 \\
\hline
\end{tabular}

\begin{tabular}{|c|r|r|c|}
\hline Total & 99.89 & 99.94 & 99.92 \\
\hline Trace element [ppm] & \multicolumn{3}{|c|}{} \\
\hline $\mathrm{As}$ & 8 & 7 & 6 \\
\hline $\mathrm{Ba}$ & 464 & 119 & 128 \\
\hline $\mathrm{Bi}$ & $<3$ & $<3$ & $<3$ \\
\hline $\mathrm{Br}$ & 3 & 4 & 3 \\
\hline $\mathrm{Cd}$ & 6 & 5 & 6 \\
\hline $\mathrm{C}$ & 40 & 9 & 9 \\
\hline
\end{tabular}

\begin{tabular}{|l|r|}
\hline $\mathrm{Ce}$ & 40 \\
\hline $\mathrm{Co}$ & 18 \\
\hline $\mathrm{Cr}$ & $<5$ \\
\hline
\end{tabular}

\begin{tabular}{|c|c|}
\hline $\mathrm{Cu}$ & 18 \\
\hline $\mathrm{Ga}$ & 16 \\
\hline $\mathrm{Hf}$ & \\
\hline
\end{tabular}

La

\begin{tabular}{|l|l}
\hline $\mathrm{Mo}$ & $<2$ \\
\hline $\mathrm{Nb}$ & \\
\hline $\mathrm{Ni}$ & \\
\hline
\end{tabular}

\begin{tabular}{|l|r|r|c|}
\hline $\mathrm{Nb}$ & 9 & 7 & 8 \\
\hline $\mathrm{Ni}$ & 4 & 19 & 21 \\
\hline $\mathrm{Pb}$ & 11 & 10 & 11 \\
\hline $\mathrm{Rb}$ & 82 & 40 & 38 \\
\hline $\mathrm{Sn}$ & $<2$ & $<2$ & $<2$ \\
\hline $\mathrm{Sr}$ & 252 & 363 & 349 \\
\hline $\mathrm{Th}$ & 10 & $<3$ & $<3$ \\
\hline $\mathrm{U}$ & 4 & 3 & 3 \\
\hline $\mathrm{V}$ & 103 & 145 & 153 \\
\hline $\mathrm{Y}$ & 24 & 14 & 16 \\
\hline $\mathrm{Zn}$ & 49 & 68 & 65 \\
\hline $\mathrm{Zr}$ & 149 & 72 & 74 \\
\hline
\end{tabular}

K-Beta (1.39222 A). Peak search parameters set defined by (PC-APD): minimum of 2 nd derivative, minimum peak tip width -2 Theta (0.00 and 1.00), peak base width -2 Theta (2.00), and minimum significance -0.75 .

Two representative samples of outcropping granite apophyses were selected for SHRIMP zircon dating: tonalite (KZ50) from the NW slope of Kalwaria Hill near Bardo Śląskie, and syenogabbro (KZ54) from the southern slope of Myszak Hill east of Dębowina village (Fig. 2). Approximately $5 \mathrm{~kg}$ of rock were crushed and the heavy mineral fraction (60-250 $\mu \mathrm{m})$ sepa- rated using standard low-contamination heavy liquid and magnetic separation procedures. Zircon grains were handpicked, mounted in epoxy resin with reference zircon SL13 (U = $238 \mathrm{ppm})$ and TEMORA $2\left({ }^{206} \mathrm{~Pb}^{\star} /{ }^{238} \mathrm{U}=0.06683\right)$, polished and Au coated for SHRIMP analysis at the Research School of Earth Sciences, ANU, using procedures described by Williams and Claesson (1987). The data were processed by methods described by Williams (1998, and references therein) using $P R A W N$ and $L E A D$ software written by $T$. Ireland. Concordia diagrams were prepared using ISOPLOT software written by $\mathrm{K}$. Ludwig. Individual analyses are plotted with $1 \sigma$ error ellipses, and uncertainties in the mean ages, which include the uncertainty in the standardization, are quoted at the $95 \%$ confidence level ( $t \sigma$ where " $t$ " is Student's $t$ ). Corrections for common $\mathrm{Pb}$ were made using ${ }^{204} \mathrm{~Pb}$ for the plots and ${ }^{207} \mathrm{~Pb}$ for the age calculations.

\section{GEOLOGICAL SETTING OF THE STUDIED AREA}

The samples collected for SHRIMP zircon U-Pb dating were located in the western parts of the KZS Granite Pluton (KZS; Fig. 1). The first sample was collected from outcrops of the Graniec-Bardo apophysis from the western slopes of Kalwaria Hill and the second sample from the apophysis of Myszak Hill (Fig. 2). The Graniec-Bardo apophysis is ca. $5 \mathrm{~km}$ in length, but not fully exposed. It is the most northwesterly apophysis of the KZS. The apophysis is composed of dark grey medium- and fine-grained tonalite and granodiorite (Wierzchołowski, 1969). The intrusion near Bardo Śląskie is triangular in shape, with the top oriented to the SE. The triangular outcrop area is ca. $250 \mathrm{~m}$ wide and ca. $900 \mathrm{~m}$ high (Oberc, 1957). According to Finckh (1929) the granitoids are cut on the W and NW side by faults, and on the $E$ are in contact with altered Carboniferous greywackes of the culm facies. On the geological map of Oberc et al. (1994) the Graniec-Bardo apophysis is shown cutting the Upper Devonian Mikołajów Schist Formation and Visean flysch that consists of mudstones, claystones and greywacke sandstones of the undivided Srebrna Góra, Czerwieńczyce and Opolnica formations. The Graniec-Bardo apophysis directly intruded the the Dzbanów Syncline in the north and the Jodłowa Syncline in the south (Fig. 3; Oberc, 1972). The Mikołajów Schist Formation here consists of claystones, mudstones and siliceous schists (Oberc et al., 1994). The Mikołajów schists are strongly folded and together with the Mississippian rocks form nappes which outline a narrow secondary synclinal folding (Oberc, 1972). These folds have WNW-ESE axes and southern vergence. Numerous amphibolite and hornfels enclaves have been described within tonalites from Bardo Śląskie (Wierzchołowski, 1976). The enclaves are small, and mostly ellipsoidal or of disc shape. The small amphibolite enclaves are strongly granitised and characterized by mineral compositions matching those of the tonalite host. The bigger discoid enclaves preserve relict structures of amphibolites. They are characterized by higher contents of hornblende and biotite, and lower contents of quartz and microcline, compared to the tonalite. Siliciclastic schists or claystones and mudstones are found near the contacts with the apophysis. Conodonts show that at least some of these rocks are of Famennian age (ca. 370-360 Ma) and the presence of abundant radiolaria suggests an abyssal sedimentary environment (Haydukiewicz, 1974).

Auriferous mineralisation has been discovered along the Bardo-Graniec apophysis in the area near Bardo Śląskie (Mikulski, 1999). The ore mineralisation is of a contact metasomatic type, but the precise position and geometry of the ores and gold reserves are not defined yet. Gold-bearing sulfide 


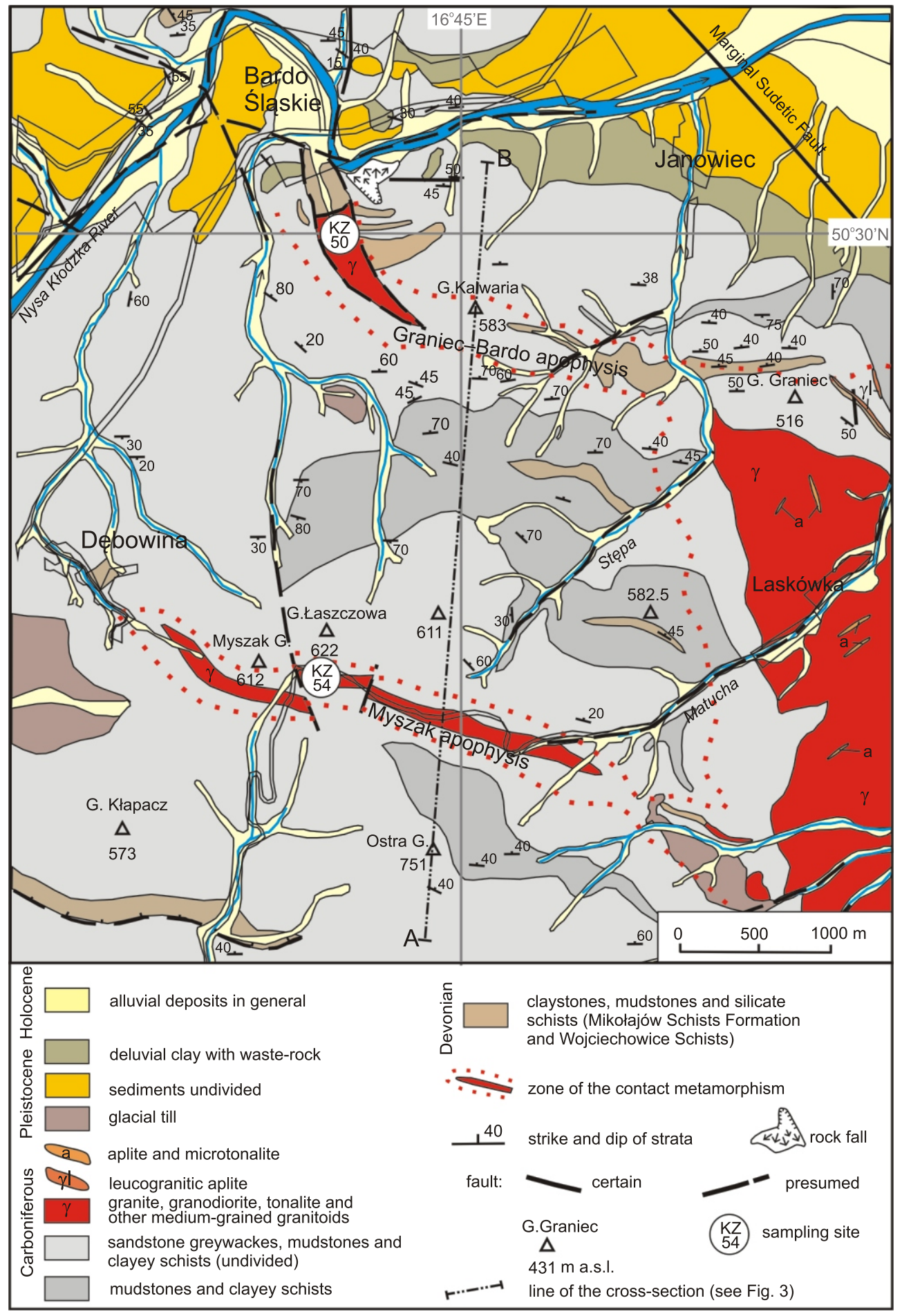

Fig. 2. Geological map of the setting of the apophyses and sampling sites in the western part of the Kłodzko-Złoty Stok Pluton (KZS), according to Gaździk (1957), Cwojdziński (1974), Emerle-Tubielewicz (1979) and Oberc et al. (1994) 


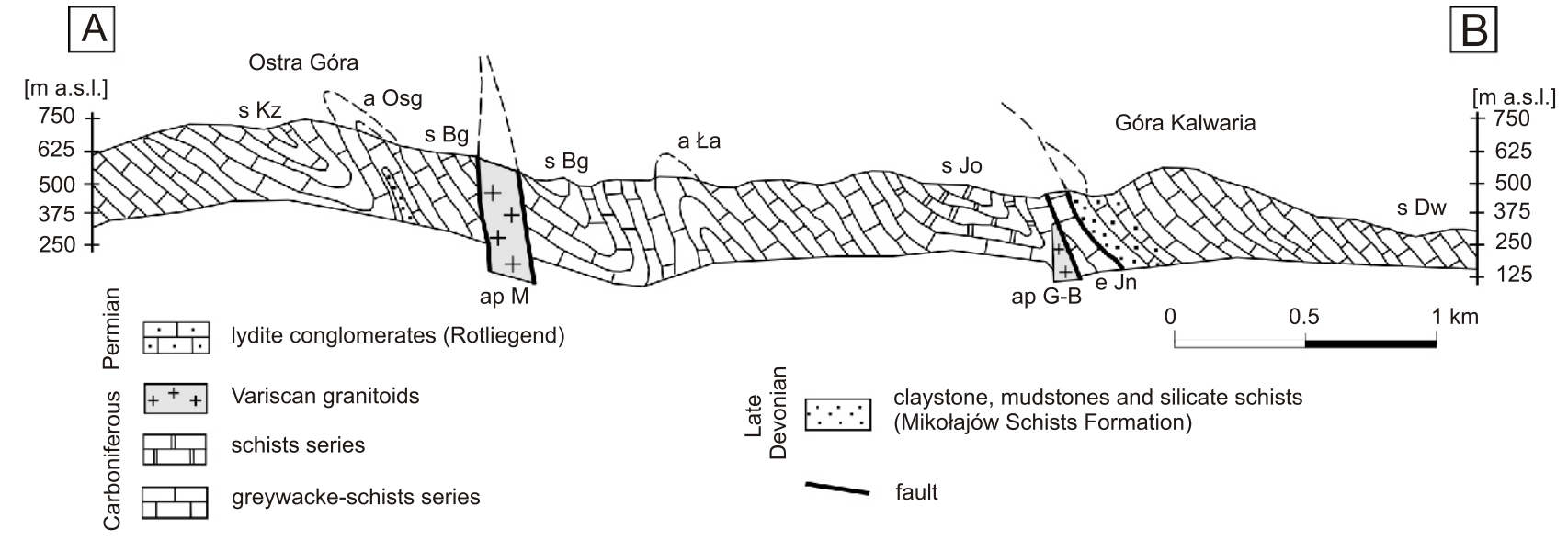

Fig. 3. Geological cross-section of the KZS apophyses in the eastern part of the Bardo Unit (according to Oberc, 1972)

ap M - Myszak apophysis; ap G-B - Graniec-Bardo apophysis; a Ła - Łaszczowa Anticline; a Osg - Ostra Góra Anticline; e Jn Janowiec element; s Bg - Boguszyn Syncline; s Dw - Dzbanów Syncline; s Jo - Jodłowa Syncline; s Kz - Kłapacz Syncline

mineralisation (5-10 ppm $\mathrm{Au}$ ) occurs as quartz-carbonate lode/veins (?) within a WNW-ESE trending tectonic zone that separates Upper Devonian-Mississippian flysch of the Bardo Unit from the Graniec-Bardo apophysis (Mikulski, 1998, 2005). Carboniferous (Mississippian) greywackes underwent strong metasomatic alteration such as silicification, sulfidation, carbonatisation, sericitisation, chloritisation and prehnitisation, and have been changed by hydrothermal fluid migration connected with the KZS.

The Myszak apophysis is located ca. $2 \mathrm{~km} \mathrm{~S}$ of the Graniec-Bardo apophysis in the western part of the KZS. The Myszak apophysis, ca. $3.5 \mathrm{~km}$ long, intruded the sedimentary rocks of the Bardo Unit which are represented by undivided and intercalated greywacke sandstones, mudstones, and clay schists of Visean age and Devonian sediments (Cwojdziński, 1974; Emerle-Tubielewicz, 1979). Devonian rocks are represented by the Mikołajów Schist Formation and Wojciechowice Beds which are exposed near Wojciechowice. These rocks form folds of WNW-ESE to W-E orientation and have southern vergence. Between the Myszak and Graniec-Bardo apophyses they form, in order, the Janowiec Syncline, the Łaszczowa Anticline and on the southern side of the Myszak apophysis, the Ostra Góra Anticline and Kłapacz Syncline (Fig. 3; Oberc, 1972). The Myszak apophysis is aligned in conformity with the direction of fold structures in this region (WNW-ESE; Emerle-Tubielewicz, 1979). The apophyses in the western part of the KZS cut folds (both synclinal- and anticlinal forms) which were classified as the Sudetic phase of the Variscan orogeny, leading to the suggestion by Oberc (1957) that the intrusions were emplaced later, e.g., during the Asturian Phase.

Devonian and Carboniferous sediments close to the contacts with the granitoid apophyses underwent zonal contact metamorphism, forming hornfels. These rocks include dark grey pinite-biotite hornfels associated with hornfels containing garnets (Wierzchołowski, 1976). The matrix in light or dark grey greywacke sandstones is strongly recrystallised. Similar to the altered sandstones are strongly altered fine-grained rocks of dark grey or brown grey colour which differ in containing pyroclastic materials and lower contents of rock fragments. In dark grey mudstones beside recrystallised fine-grained matrix of quartz-mica composition appear isometric blasts of garnet and K-spar. The width of the contact aureole along the apophyses may reach up to a few kilometres (Oberc, 1972; Wierzchołowski, 1976).

\section{GEOCHEMICAL AND PETROGRAPHIC FEATURES OF GRANITOID APOPHYSES}

The granitoid samples from the Graniec-Bardo apophysis studied here (e.g., KZ50) are dark grey, medium- and fine-grained, with hypidiomorphic-granular texture, random structure and isotropic fabric (Fig. 4A). They are composed of plagioclase, K-spar, quartz, hornblende, biotite and small amounts of zircon, titanite, ilmenite, magnetite, pyrite, apatite, calcite and epidote (Fig. 4C, E). The grain size is $2-5 \mathrm{~mm}$, but generally the K-spar and quartz is much finer than the plagioclase. Hornblende may form aggregates which are subject to chloritisation and calcification. Biotite commonly forms overgrowths on hornblende, and tiny aggregates in places intergrown with opaque minerals. Albite occurs mostly as replacements of plagioclase or infills micro-fractures due to hydrothermal activity. Based on detailed petrographic studies of the granitoids from the Bardo apophysis that show their low content of microcline $(<0.4 .8 \mathrm{vol} . \%)$ and very high contents of plagioclase (46.9-58.0 vol.\%) and quartz (17.9-29.7 vol.\%), Wierzchołowski (1969) strongly argued for their classification as tonalites.

The granitoid sample from the Myszak apophysis (KZ54) is dark grey, fine-grained of hypidiomorphic-granular texture and composed of plagioclase, amphibole (hornblende), biotite with calcite, chlorite and Ti- and Fe-oxides (Fig. 4B, D, F). Our XRD analyses of the KZ50 sample from the Graniec-Bardo apophysis identified quartz, K-feldspar (orthoclase and sanidine), plagioclase (anorthite, $\mathrm{Na}$-anorthite and $\mathrm{Ca}$-albite), amphibole (Mg-hornblende) and traces $(<2 \%)$ of calcite and clay minerals (Fe-chlorite and illite). In the KZ54 sample from the Myszak apophysis plagioclase (Na-anorthite and minor albite), amphibole (Mg-hornblende), calcite and minor Fe-chlorites and illite were recognized.

The major element oxides and trace elements for 3 apophysis samples are shown in Table 1. KZ54 and KZ54/B are low- $\mathrm{SiO}_{2}$ (ca. 50 wt. \%) and $\mathrm{K}_{2} \mathrm{O}$ (ca. 1 wt. \%) and high $\mathrm{Al}_{2} \mathrm{O}_{3}$ (ca. 21 wt. \%), $\mathrm{Fe}_{2} \mathrm{O}_{3}$ (ca. 8 wt.\%) and $\mathrm{CaO}$ (ca. 9 wt.\%) rocks. The sampled rocks from the Graniec-Bardo and Myszak apophyses on the $\left(\mathrm{Na}_{2} \mathrm{O}+\mathrm{K}_{2} \mathrm{O}\right)$ vs. $\mathrm{SiO}_{2}$ diagram plot in the transition between quartz diorite and granodiorite (KZ50) and syenogabbro (KZ54 and KZ54/B) fields. On the R1 vs. R2 diagram (Roche et al., 1980), these rocks plot as tonalite and oliv- 

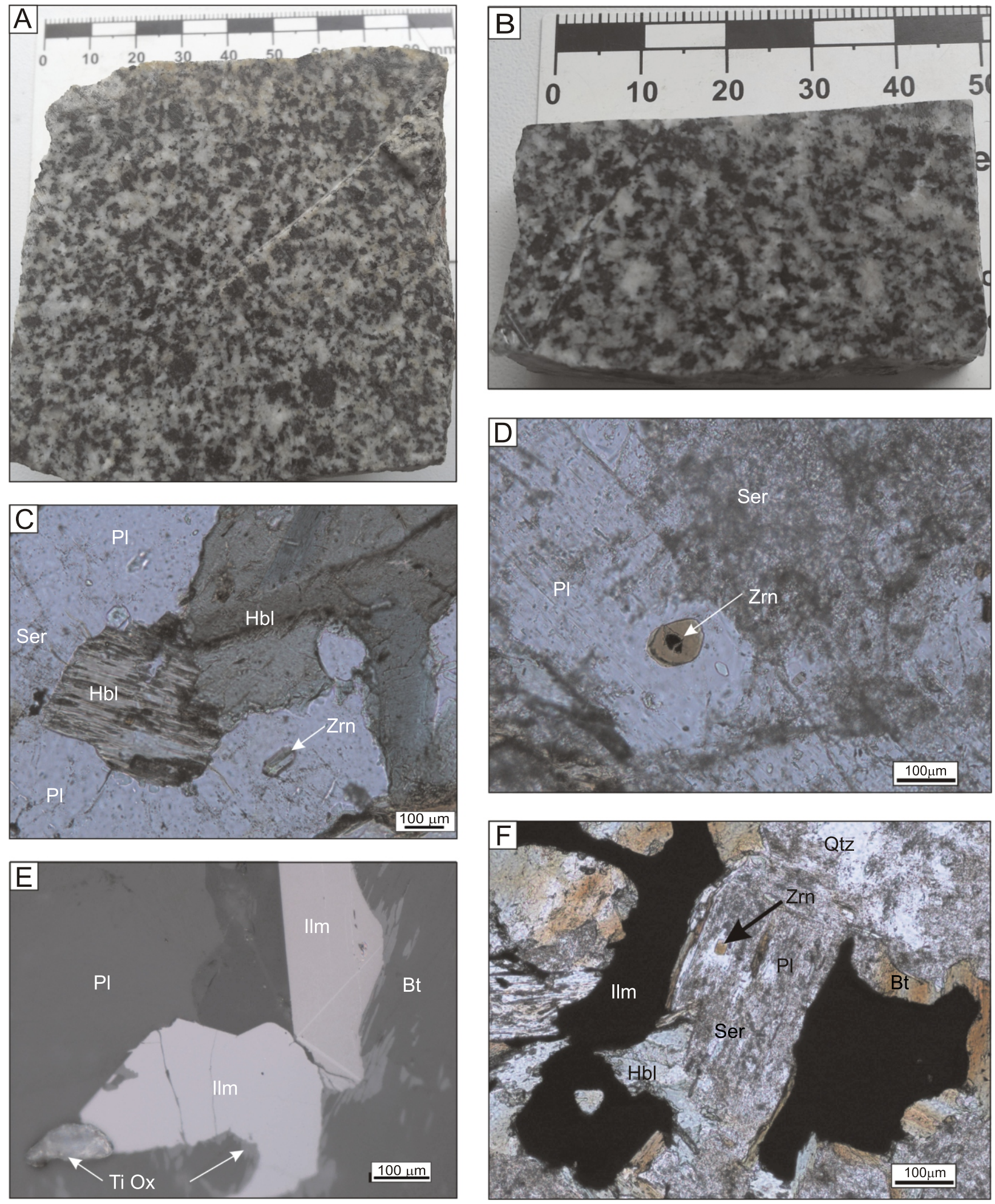

Fig. 4A, B - characteristic views of the igneous rocks from the apophyses in the western part of the Kłodzko-Złoty Stok Granite Pluton, they are dark gray and medium-grained rocks with hypidiomorphic-granular texture, random structure and isotropic fabric; C, D and F- microscope view of typical occurrences of zircon grains marked by arrows (plane polarized light); E-ilmenite replacement by titanium oxides in reflected light

A, C, E - tonalite (KZ50) from the Graniec-Bardo apophysis; B, D, F - syenogabbro (KZ54) from the Myszak apophysis; Bt - biotite, Hbl - hornblende; IIm - ilmenite; PI - plagioclase; Ser - sericite; Ti Ox - titanium oxides; Qtz - quartz; Zrn - zircon 
ine gabbros (Fig. 5). KZ 50 samples have major-oxides contents typical for tonalites from KZS. Samples have low $\mathrm{Ba}, \mathrm{Rb}$, Th and $U$ contents. If we compare these results with other published data we see that most of the KZS rocks are representing by granitoids of different composition such as tonalite, diorite, monzodiorite, granodiorite and gabbros, which indicate variable source-rock compositions. On the diagram of $\mathrm{SiO}_{2}$ vs. $\mathrm{Na}_{2} \mathrm{O}+$ $\mathrm{K}_{2} \mathrm{O}$, syenogabbro samples (KZ54 and $\left.\mathrm{KZ} 54 / \mathrm{B}\right)$ are located in the subalkaline field and the tonalite sample in the calc-alkaline field and, on the $\mathrm{SiO}_{2}$ vs. $\mathrm{K}_{2} \mathrm{O}$ diagram, apophysis samples plot in the field of medium potassic rocks. $\mathrm{Zr} / \mathrm{Nb}$ values (ca. 10-17) of the apophysis rocks are indicative of their transition position between calc-alkalic and tholeitic rocks. The A/CNK index of 2 for samples KZ54 and KZ54/B is close to the 1.1 line separating I-type granite from S-type granite. For sample KZ50, the value of this index is almost 1.2 and falls in the peraluminous field. However, the average A/CNK coefficient for the KZS igneous rocks of 0.95 ( $n=68$; range $0.70-1.30$, Mikulski et al., 2013) allows classification as I-type granite in the sense of Chappel and White (1974) with metaluminous rocks in a dominant role according to the classification of White and Chappell (1977). The wide range of the A/CNK coefficients is a characteristic feature of the KZS igneous rocks, and indicates different magma sources, mixing and differentiation processes resulting in magma compositions transitional from mafic diorite to felsic granites (Wierzchołowski, 1976). On the K/Rb vs. $\mathrm{SiO}_{2}$ diagram (cf. Blevin, 2003), three apophysis samples lie in the field of moderately-evolved granitoids.

In terms of geotectonic setting, the studied granitoids plot in the island arc (VAG) and syn-collisional (syn-COLG) granite fields on the $\mathrm{Y}-\mathrm{Nb}$ diagram of Pearce et al. (1984) and they fall in the collisional field on the $\mathrm{Y}+\mathrm{Nb}$ vs. Rb plot (Pearce et al., 1984). On the multicomponent discrimination diagram R1 vs. R2 (Batchelor and Bowden, 1985), the tonalite and syenogabbro fall like most of the KZS granitoids within the pre-plate-collision group. The remainder of the KZS granitoids are transitional to the post-collision uplift group (Fig. 5; Mikulski et al., 2013).

\section{SHRIMP ZIRCON DATING}

The first sample of tonalite (KZ50) from the Graniec-Bardo apophysis was collected from a small granitoid quarry located SE of Bardo Śląskie near the 7th Station of the Cross leading to the Góra Kalwaria Hill (Figs. 1 and 2; KZ50 geographic co-ordinates are: N 50³0'01.3”, E 01644' 15.4"). The selected zircon grains from KZ50 are medium to large $(\sim 100-200 \mu \mathrm{m}$ diameter), glassy clear, pale brownish, sharply euhedral crystals with

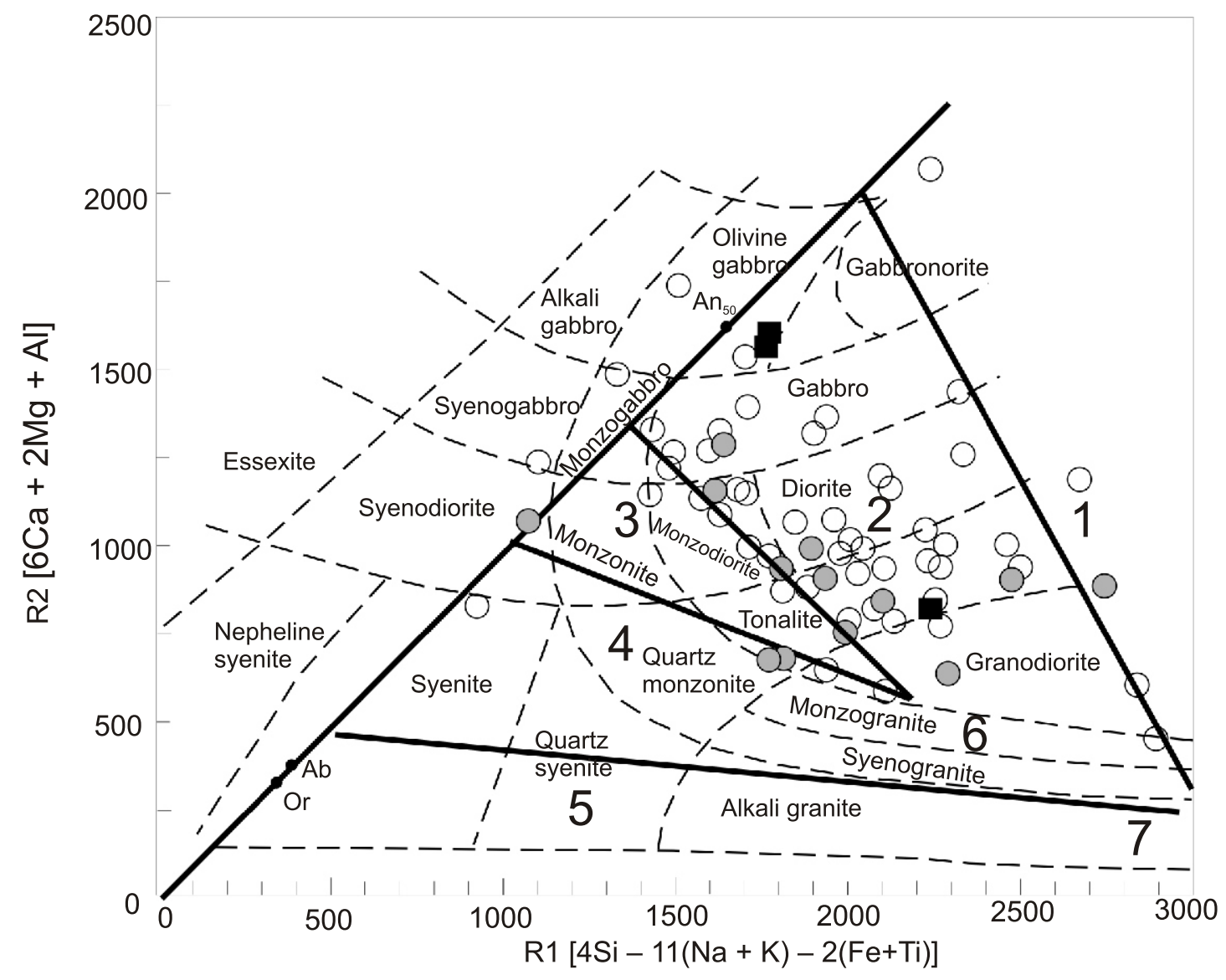

Fig. 5. Igneous rocks of the Kłodzko-Złoty Stok Granite Pluton and magmatic associations in the R1 vs. R2 multicationic plot of Batchelor and Bowden (1985)

$\mathrm{R} 1=4 \mathrm{Si}-11(\mathrm{Na}+\mathrm{K})-2(\mathrm{Fe}+\mathrm{Ti}) ; \mathrm{R} 2=6 \mathrm{Ca}+\mathrm{Mg}+\mathrm{Al} ; 1$ - tholeitic group (mantle fractionates), 2 - calc-alkaline and trondhjemitic group (pre-collision of plates), 3 - high potassic calc-alkaline group (post-collision uplift), 4 - sub-alkaline monzonitic group (late-orogenic), 5 - alkaline and peralkaline group (anorogenic), 6 - anatectic two-mica leucogranites (syn-collision), 7 - post-orogenic; black square - analyses from the present study, grey circle - analyses from Mikulski et al. (2013), open circle - analyses from Borkowska (1957), Pendias and Maciejewski (1959), Wierzchołowski (1976) and Lorenc (1991) 


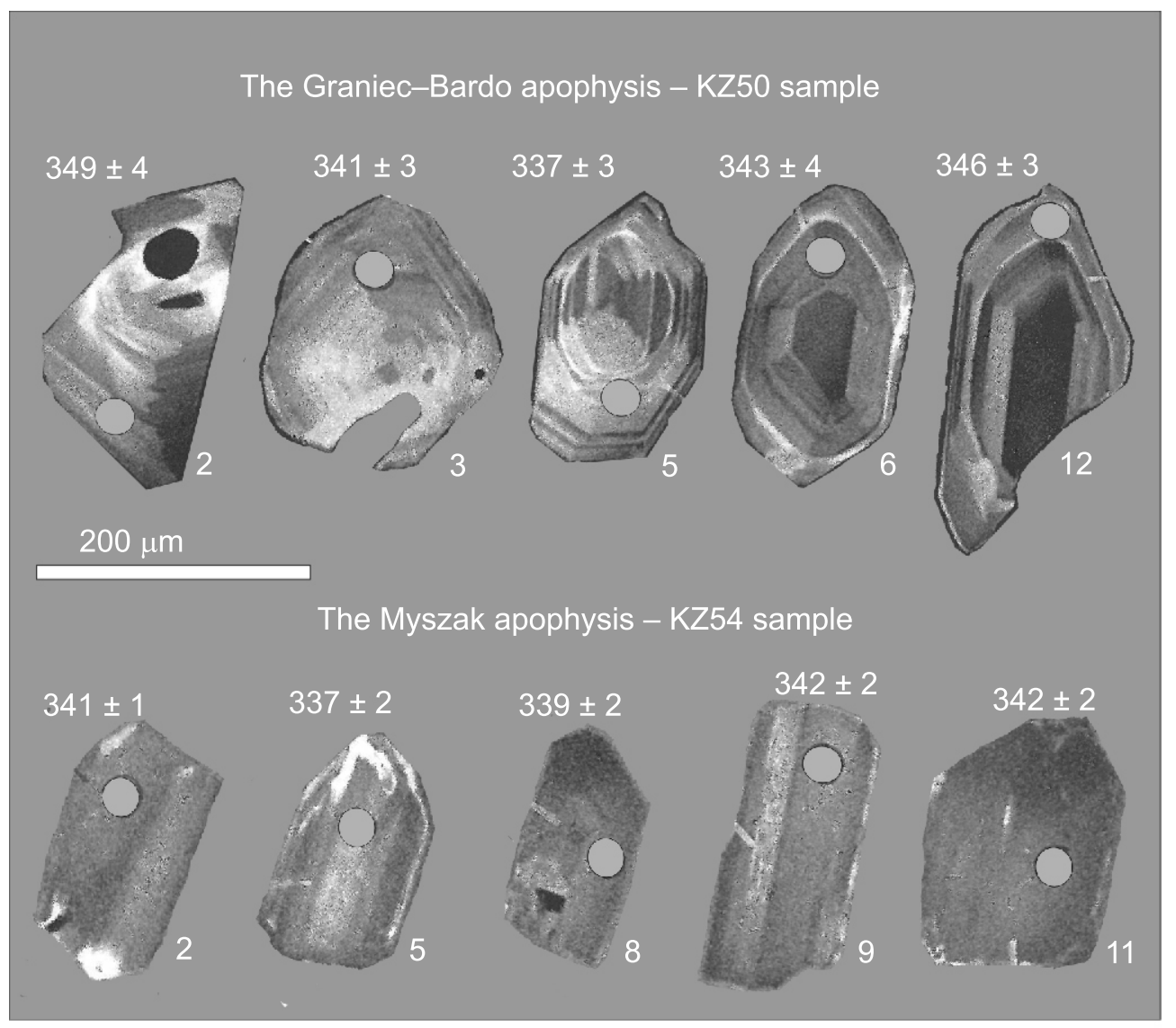

Fig. 6. Cathodoluminescence images of selected zircon grains from the studied magmatic rocks of the Kłodzko-Złoty Stok Granite Pluton

mostly complex crystal forms ( $\{110\}$ and $\{211\}$ faces) and low aspect ratios of $1-3$. They have a small number of relatively large rounded to amoeboid inclusions, very few mineral inclusions and very few fractures. The grains show strong to very strong cathodoluminescence revealing complex but consistent growth textures (Fig. 6). The centres of the grains are mostly broadly zoned, with weak concentric zoning and common sector zoning. The outer parts of the grains in many cases show finer concentric zoning. There are no texturally discordant cores. Twelve $\mathrm{U}-\mathrm{Pb}$ analyses of zircon with a range of zoning patterns (ca. $50 \%$ of each type) show a narrow range of low $U$ contents $\left(\sim 180-300 \mathrm{ppm}\right.$; Appendix $\left.1^{*}\right)$ and a narrow range of $\mathrm{Th} / \mathrm{U}(0.27-0.45)$. Common $\mathrm{Pb}$ contents are very low. The isotopic analyses are all concordant within analytical uncertainty and form a single tight cluster with no significant range in radiogenic ${ }^{206} \mathrm{~Pb} /{ }^{238} \mathrm{U}(\mathrm{MSWD}=1.8)$. Combined, all twelve analyses give a weighed mean ${ }^{206} \mathrm{~Pb} /{ }^{238} \mathrm{U}$ age of $341.6 \pm 2.8 \mathrm{Ma}$ (95\% c.l.; Fig. 7).

The second sample (KZ54) was collected from an area east of Dębowina village near the outcrops of the Myszak Hill apophysis which is cut there by a NE-SW trending fault near the road from Wojciechowice to Laskówka (Fig. 2; KZ54 geographic co-ordinates are: N 50²8'33.5”, E 01644'01.3”). The zircon from KZ54 is mostly badly damaged by alteration and partial dissolution. Very few grains appear to be even remotely suitable for $\mathrm{U}-\mathrm{Pb}$ dating. The zircon grains selected are fine to medium (50-150 $\mu \mathrm{m}$ diameter), partly clear, colourless to pale brown subhedral to anhedral crystals with broadly simple pris- matic shapes (Fig. 6). Most crystal faces are weakly to deeply pitted by corrosion, giving the grains a frosted appearance. Most grains are closely fractured and many contain a high abundance of dusty inclusions. There are very few inclusions larger than $5 \mu \mathrm{m}$. All the grains show a very weak cathodoluminescence and show little evidence of growth zoning. The luminescence texture is mostly bland throughout the grains, but with more strongly luminescent highlights in irregular patches, along fractures, and along those grain boundaries that have been corroded - consistent with corrosion associated with the loss of trace elements and partial recrystallisation. Twelve $\mathrm{U}-\mathrm{Pb}$ analyses of the best quality zircon, avoiding imperfections, inclusions, corroded areas and areas with the weakest luminescence, show a range of high to very high $U$ contents (1030-3470 ppm), mostly very uniform Th/U (0.5-0.6), and consistently very low common $\mathrm{Pb}$ contents (Appendix 1). The isotopic compositions are all concordant within analytical uncertainty but show a significant range in radiogenic ${ }^{206} \mathrm{~Pb} /{ }^{238} \mathrm{U}(\mathrm{MSWD}=4.0)$. Two of the analysed spots have $\mathrm{U}$ contents above the threshold ( $2500 \mathrm{ppm})$ at which matrix effects in the measurement of $\mathrm{Pb} / \mathrm{U}$ have been observed (Williams and Hergt, 2001), but there is no systematic relationship between ${ }^{206} \mathrm{~Pb} /{ }^{238} \mathrm{U}$ and $U$ content, so no correction was applied. The scatter is due to three analyses that are significantly lower than the rest $(4.1,6.1,7.1)$, probably because of radiogenic $\mathrm{Pb}$ loss. The remaining nine analyses with equal ${ }^{206} \mathrm{~Pb} /{ }^{238} \mathrm{U}$ within uncertainty (MSWD $=1.6$ ) give a weighted mean age of $341.4 \pm 2.2 \mathrm{Ma}$ (95\% c.l.; Fig. 8).

\footnotetext{
* Supplementary data associated with this article can be found, in the online version, at doi: 10.7306/gq.1141
} 


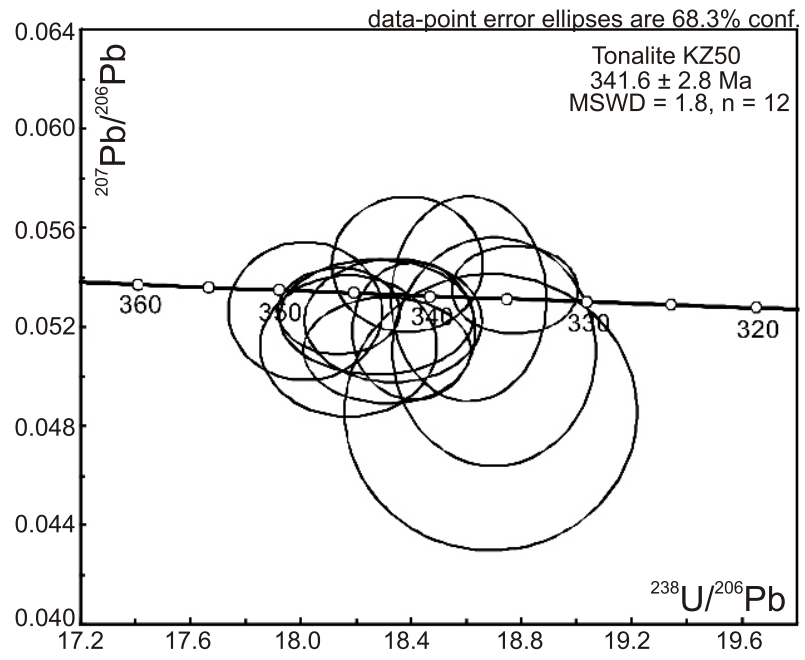

Fig. 7. Concordia diagram showing SHRIMP zircon U-Pb analyses from a tonalite sample from the Graniec-Bardo apophysis

The error ellipses on the concordia are $1 \sigma$ precision estimates of radiogenic compositions corrected for common $\mathrm{Pb}$ using ${ }^{204} \mathrm{~Pb}$;

the crosses are the analyses before common $\mathrm{Pb}$ correction

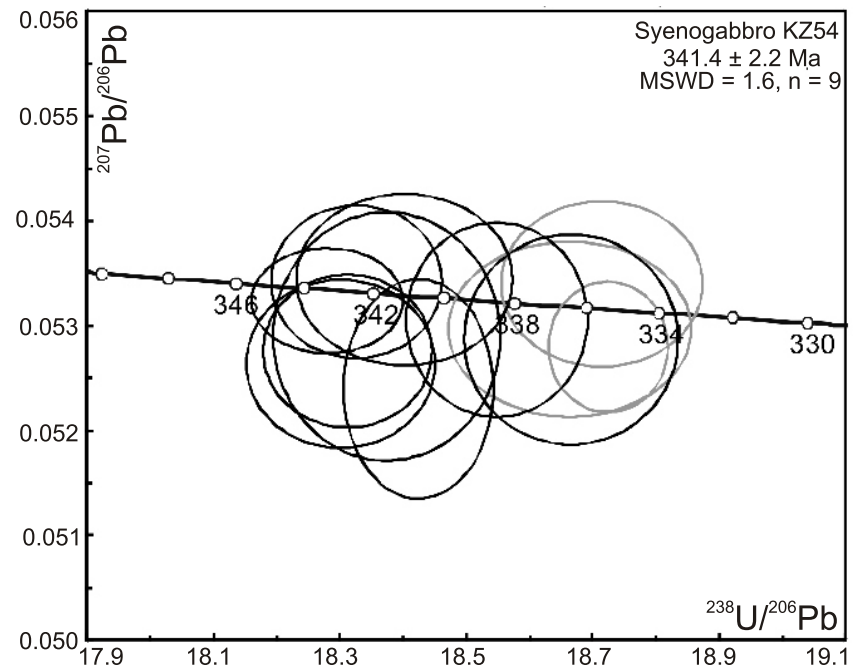

Fig. 8. Concordia diagram showing SHRIMP zircon U-Pb analyses from a syenogabbro sample from the Myszak apophysis

The error ellipses on the concordia are $1 \sigma$ precision estimates of radiogenic compositions corrected for common $\mathrm{Pb}$ using ${ }^{204} \mathrm{~Pb}$; the crosses are the analyses before common $\mathrm{Pb}$ correction; light ellipses are analyses omitted from the calculation of the weighted mean ${ }^{206} \mathrm{~Pb} /{ }^{238} \mathrm{U}$ age

\section{DISCUSSION}

The zircon U-Pb dating of igneous rock samples from the Graniec-Bardo and Myszak apophyses in the western part of the Kłodzko-Złoty Stok Granite Pluton give the same ages $341.6 \pm 2.8$ and $341.4 \pm 2.2 \mathrm{Ma}$. These apophyses intrude folded Devonian and Visean flysch rocks of the Bardo Unit. These zircon dates compliment and are in agreement with our earlier $\mathrm{U}-\mathrm{Pb}$ isotopic results for zircon samples from the eastern and central parts of the KZS Granite Pluton (Mikulski et al., 2013). All of the available U-Pb dates from the KZS suggests that the main zircon populations represent magmatic events during the Visean, from ca. 341 to $331 \mathrm{Ma}$ (Fig. 9). The earliest phase of magmatism is represented by the granitoid intrusions of the Graniec-Bardo and Myszak apophyses which are coeval with quartz monzodiorite from Żelazno (Z248 sample $340.2 \pm 2.5 \mathrm{Ma}$ ), hornblende monzonite from Droszków (D148 sample $-339.5 \pm 2.8 \mathrm{Ma}$ ) and the biotite-hornblende granodiorite from Chwalisław (M10, $336.7 \pm 2.3 \mathrm{Ma}$ ). Given the analytical uncertainties, these five age estimates are indistinguishable. Slightly later magmatism is represented by the tonalite from Ptasznik Hill (P9, 331.5 $\pm 2.6 \mathrm{Ma}$ ) and the spessartite dyke from Chwalisław (M11, 333.1 $\pm 3.1 \mathrm{Ma})$. The KZS granitoids are a group of composite intrusions consisting mainly of biotite- and hornblende-rich granitoids with abundant mafic magmatic enclaves, and with igneous plutonic rocks of intermediate composition that reflect mixing and mingling between felsic and mafic magmas (Wierzchołowski, 1976). This process could have resulted in the formation of granodioritic or/and quartz monzodioritic magmas at ca. 342-337 Ma (samples from Bardo, Wojciechowice, Żelazno, Droszków and Chwalisław) with later fractional crystallisation of hornblende from wet magmas at ca. 333 Ma producing spessartitic compositions such as at Chwalisław (Mikulski et al., 2013). The tonalite from Ptasznik Hill and its magmatic zircon have different trace element and REE contents from those of the other samples. Both are strongly enriched in incompatible elements, indicating advanced fractionation or REE enrichment of the parental magma which yields an age at ca. $331.5 \pm 2.6 \mathrm{Ma}$.

Our current dating strongly suggests that the earliest stage of KZS granodiorite magma emplacement (ca. $341 \mathrm{Ma}$ ) was probably connected with the strong development of the local metasomatic-type polymetallic auriferous-bearing sulfide mineralisation near Bardo Śląskie (Mikulski, 1998, 2005). In this area, Devonian and Mississippian sedimentary rocks along the contact with the Graniec-Bardo apophysis underwent strong contact alteration. Rocks occurring in the bottom parts of Carboniferous (Mississippian) greywacke and amphibolite enclaves together with the surroundings rocks underwent strong alteration such as hornfelsing and granitisation at high temperature $\left(>700^{\circ} \mathrm{C}\right.$, e.g., Wierzchołowski, 1976; Bagiński, 2007). The country rocks were strongly silicified, feldspathised during early high temperature stages and, later, underwent sulfidisation, sericitisation, prehnitisation, carbonatisation, chloritisation and epidotisation. Strongly altered rocks with abundant sulfide mineralisation have a characteristic metasomatic texture. The first stage of auriferous sulfide precipitation was likely connected with the thermal influence of the intruded Graniec-Bardo tonalite apophysis. Moreover, the main stage of auriferous skarn type mineralisation known from the eastern metamorphic cover of the KZS at the Złoty Stok Au-As deposit (e.g., Mikulski and Speczik, 2008) may have formed at the same time, as already suggested by Mikulski (2007). In contrast, the contact-metasomatic scheelite-titanite mineralisation reported from the Ptasznik prospect (Mikulski, 2000) corresponds to the youngest and more fractionated magma emplacement (ca. $331 \mathrm{Ma}$ ).

Early K-Ar ages determined for the KZS granitoids were interpreted as indicating granite emplacement in the Early Permian at ca. $298 \mathrm{Ma}$ (Depciuch, 1972). Our current zircon dating of the granitoids contradicts that interpretation by showing, instead, that they are of Middle Mississippian (Visean) age. Geochemical and petrographic study of the samples from the Graniec-Bardo and Myszak apophyses confirm that the KZS Massif consists of granitoids with wide ranges of compositions of some major element oxides such as $\mathrm{SiO}_{2}$ (ca. 50-68 wt.\%), $\mathrm{Al}_{2} \mathrm{O}_{3}(17-21$ wt. \%), and $\mathrm{CaO}$ (4-10 wt.\%). The contents of in- 


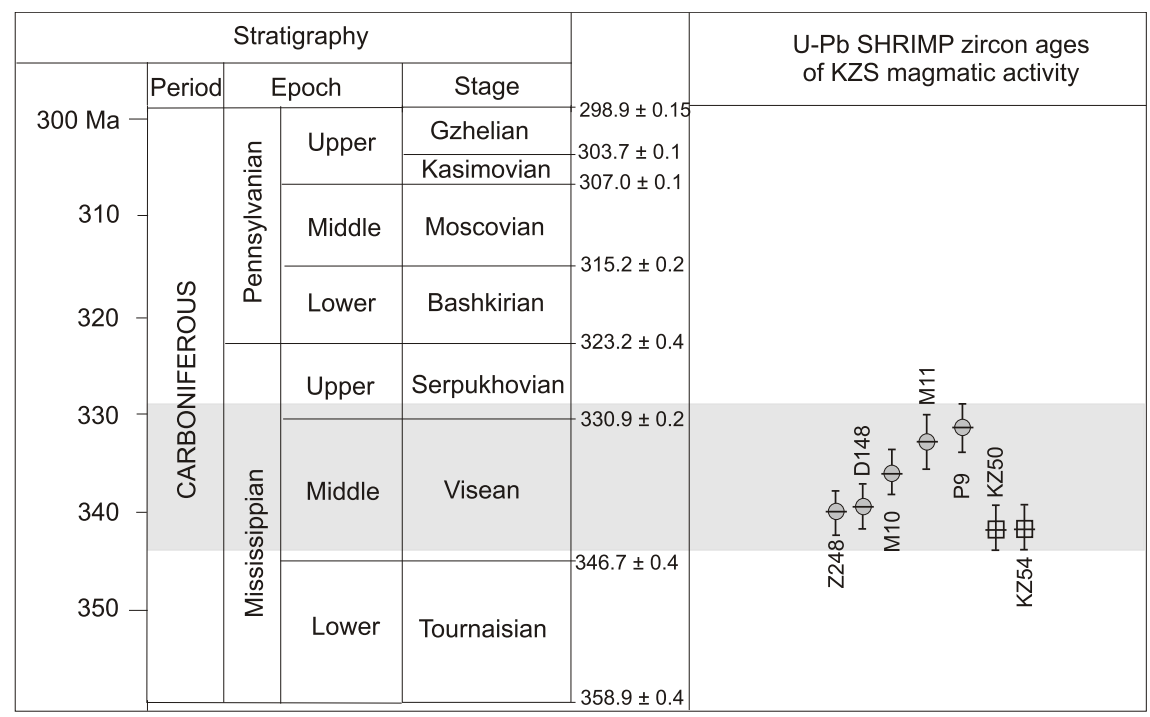

Fig. 9. Compilation of SHRIMP zircon data (samples KZ50 and KZ54) and other data (according to Mikulski et al., 2013) from the Kłodzko-Złoty Stok Granite Pluton on a stratigraphic chart (according to Gradstein et al., 2012 and Cohen et al., 2013)

compatible and compatible elements indicate a heterogeneous lithospheric source for the magmas that produced the granitoids. If we compare the geochemical and petrographic composition of the tonalite sample from the Graniec-Bardo apophysis with the sample from the Myszak apophysis, it is evident that the latter is much more basic in composition and represent a more mafic and older constituent of the magma. The KZS granitoids are mainly of metaluminous and, to a minor degree, weakly peraluminous, highly potassic I-type granitoids containing abundant mafic enclaves (Mikulski et al., 2013). Geochemically, they may be classified as syn-collisional granites according to the $\mathrm{Nb}$ vs. Y diagram of Pearce et al. (1984). On the R1 vs. R2 diagram (Batchelor and Bowden 1985), the samples from the KZS plot in the fields of pre-plate-collisional granites and transitional to post-collisional uplift granites (e.g., Bachliński and Bagiński, 2007; Mikulski et al., 2013). They formed as a result of an early-stage collision between the Saxothuringian and Brunovistulian terranes.

The present dating of the KZS granitoids, and other granitoid ages from the central and eastern parts of the Sudetic Block, namely, Kudowa-Olešnice and Jawornik (Bachliński and Hałas, 2002; Białek and Werner, 2004), from the Niemcza Shear Zone on the Fore-Sudetic Block (Kryza, 2011) and from the Odra Fault Zone (Dörr et al., 2006), indicates intrusion in the Carboniferous Mississippian (Tournaisian-Visean). However, they reflect a different geotectonic setting from that of an earlier episode of emplacement of syn-tectonic to post-collisional granitoids, despite their quite similar petrographic and geochemical characteristics.

\section{CONCLUSIONS}

1. SHRIMP zircon U-Pb dating of igneous rocks from the Graniec-Bardo and Myszak apophyses from the western parts of Kłodzko-Złoty Stok Granite Pluton in the Sudetic Block (Saxothuringian Zone, Central European Variscides) indicates that the granitoids were intruded at ca. $341 \mathrm{Ma}$ in the Mississippian (Middle Visean). These results are supplementary to, and in conformity with, our earlier publication in which we presented SHRIMP dates for igneous rocks from the eastern and central parts of the KZS. However, the Graniec-Bardo and Myszak apophyses constitute the oldest parts of the KZS which formed in the earliest stage of the pluton emplacement.

2. Geochemical and petrographic studies of the dated apophysis rocks show them to be biotite- and hornblende-rich granitoids (tonalite) and syenogabbros of diverse compositions typical of rocks originating from hybrid magmas that involved variable contributions of a more basic magma component. Igneous zircon from the KZS records hypabyssal magmatism from ca. 341 to $331 \mathrm{Ma}$. The KZS magmatic episode lasted only ca. $10 \mathrm{Ma}$ and records a rapid geotectonic transition from early-stage collisional granitoid emplacement to fast orogenic uplift in this part of the Central European Variscides.

3. The post-magmatic hydrothermal activity that produced polymetallic auriferous ore mineralisation of contact metasomatic type in intimate contact with the Graniec-Bardo apophysis near Bardo Śląskie may have begun in the Visean.

Acknowledgements. The analytical work was supported by the National Committee for Scientific Research, Grant no. N N525 393739 for SM. The SHRIMP geochronology was carried out under a collaborative research agreement between the Polish Geological Institute - National Research Institute and the Research School of Earth Sciences, Australian National University. We would like to thank Prof. P. Kennan for valuable comments that highly improved our manuscript. Also many thanks are extended to M. Kusiak, R. Seltman and Z. Cymerman for their constructive remarks which improved the paper. 


\section{REFERENCES}

Awdankiewicz, M., 2007. Late Palaeozoic lamprophyres and associated mafic subvolcanic rocks of the Sudetes (SW Poland): petrology, geochemistry and petrogenesis. Geologia Sudetica, 39: $11-97$

Awdankiewicz, M., Awdankiewicz, H., Ilnicki, S., Szczepański, J., 2010. The record of differentiation and emplacement processes in lamprophyres (Kłodzko region, Sudetes, SW, Poland). Mineralogia, Special Papers, 37: 123-139.

Bachliński, R., Bagiński, B., 2007. Kłodzko-Złoty Stok granitoid massif. Archivum Mineralogiae Monograph, 1: 261-273.

Bachliński, R., Hałas, S., 2002. K-Ar dating of biotite from the Kudowa Zdrój granitoids (Central Sudetes, SW Poland). Bulletin of the Polish Academy of Sciences, Earth Sciences, 50:113-116.

Bagiński, B., 2007. P-T-t data on the contact metamorphism of metapelitic rocks induced by Kłodzko-Złoty Stok intrusion (Central Sudetes, Poland). Mineralogia Polonica Special Papers, 30: 20-21.

Batchelor, R.A., Bowden, P., 1985. Petrogenetic interpretation of granitoid rock series using multicationic parameters. Chemical Geology, 48: 43-55.

Białek, D., Werner, T., 2004. Geochemistry and geochronology of the Javornik granodiorite and its geodynamic significance in the Eastern Variscan belt. Geolines, 17: 22-23.

Blevin, P., 2003. Metallogeny of granitic rocks. Geoscience Australia, 14: 1-4.

Borkowska, M., 1957. On the granitoids of Kudowa, as compared with the main types of the acid intrusions of the Sudeten Mts. and the Sudetic foreland (in Polish with English summary). Archiwum Mineralogiczne, 21: 229-363.

Chappell, B.W., White, A.J.R., 1974. Two contrasting granite types Pacific Geology, 8: 173-174.

Cohen, K.M., Finney, S.C., Gibbard, P.L., Fan, J.X., 2013. The ICS International Chronostratigraphic Chart. Episodes, 36 199-204.

Cwojdziński, S., 1974. Szczegółowa mapa geologiczna Sudetów w skali 1:25 000, arkusz Złoty Stok. Instytut Geologiczny, Warszawa.

Cwojdziński, S., 1981. Pre-granitoid semi-lamprophyre at Rogówek (Kłodzko-Złoty Stok granitoid massif) (in Polish with English summary). Kwartalnik Geologiczny, 25 (1): 31-40.

Cymerman, Z., 1996. The Złoty Stok-Trzebieszowice regional shear zone: the boundary of terranes in the Góry Złote Mts. (Sudetes). Geological Quarterly, 40 (1): 89-118.

Depciuch, T., 1972. Absolute age of (K-Ar) granitoids from the Kłodzko-Złoty Stok Area and the Niemcza Zone (in Polish with English summary). Kwartalnik Geologiczny, 16 (1): 103-112.

Dörr, W., Żelaźniewicz, A., Bylina, P., Schastok, J., Franke, W. Haack, U., Kulicki, C., 2006. Tournaisian age of granitoids from the Odra Fault Zone (southwestern Poland): equivalent of the Mid-German Crystalline High? International Journal of Earth Sciences, 95: 341-349.

Finckh, L., 1929. Geologische Karte. Blatt Frankenstein. Berlin.

Franke, W., Żelaźniewicz, A., 2000. The eastern termination of the Variscides: terrane correlation and kinematic evolution. Geological Society Special Publications, 179: 63-86.

Gaździk, J., 1957. Szczegółowa mapa geologiczna Sudetów w skali 1:25 000, arkusz Przyłęk. Instytut Geologiczny, Warszawa.

Gradstein, F.M., Ogg, J.G., Schmitz, M.D., Ogg, G.M., eds., 2012. The Geologic Time Scale 2012. Elsevier.

Emerle-Tubielewicz, H., 1979. Szczegółowa mapa geologiczna Sudetów w skali 1:25 000, arkusz Kłodzko. Instytut Geologiczny, Warszawa.

Haydukiewicz, J., 1974. Upper Devonian conodonts from Mikołajów slates, Bardo Mts., Sudetes. Bulletin de l'Academie Polonaise des Sciences, Série de les Sciences de la Terre, 21 233-235.
Kryza, R., 2011. Early Carboniferous ( $237 \mathrm{Ma}$ ) granite intrusion in Devonian ( $400 \mathrm{Ma})$ ophiolite of the Central-European Variscides. Geological Quarterly, 55 (3): 213-222.

Lorenc, M., 1991. Remarks on genesis of the Kłodzko-Złoty Stok intrusion (comparative studies based on enclaves) (in Polish with English summary). Archiwum Mineralogiczne, 47: 79-98.

Lorenc, M., 1994. Role of basic magmas in the granitoid evolution (in Polish with English summary). Geologia Sudetica, 28: 3-112.

Mazur, S., Aleksandrowski, P., Kryza, R., Oberc-Dziedzic, T., 2006. The Variscan Orogen in Poland. Geological Quarterly, 50 (1): 89-118.

Mazur, S., Aleksandrowski, P., Turniak, K., Awdankiewicz, M. 2007. Geology, tectonic evolution and Late Palaeozoic magmatism of Sudetes - an overview. Archivum Mineralogiae Monograph, 1: 59-87

Mikulski, S.Z., 1996a. Gold mineralization in the Złoty Jar quarry near the Złoty Stok As-Au deposit (Sudetes, SW Poland) (in Polish with English summary). Przegląd Geologiczny, 44: 1205-1210.

Mikulski, S.Z., 1996b. Gold mineralization within contact-metamorphic and shear zones in the "Golden Creek" quarry - the Złoty Stok Au-As deposit area (Sudetes). Geological Quarterly, 40 (3): 407-442.

Mikulski S.Z., 1998. Gold-bearing ore mineralization from Bardo Śląskie (Central Sudetes) (in Polish with English summary). Przegląd Geologiczny, 46: 1261-1267.

Mikulski, S.Z., 1999. Scheelite and gold-bearing mineralization in the Ptasznik roof pendant, Sudetes, Poland. In: Mineral Deposits: Processes to Processing. 5th SGA meeting and 10th Quadrennial IAGOD meeting, August 22-25, 1999 (eds. C.J. Stanley et al.): 393-396. A.A. Balkema, London.

Mikulski, S.Z., 2000. Prospecting of scheelite and gold mineralization in the Ptasznik roof pendant of the Kłodzko-Złoty Stok intrusion in the Sudetes Mts. (in Polish with English summary). Biuletyn Państwowego Instytutu Geologicznego, 391: 5-88.

Mikulski, S.Z., 2005. The telluride mineralization event(s) within the Late-Variscan gold deposits in the Western Sudetes (NE part of the Bohemian Massif, SW Poland). In: Mineral Deposit Research: Meeting the Global Challenge (eds. Jingwen Mao and F.P. Bierlein): 1415-1418. Springer.

Mikulski, S.Z., 2007. The late Variscan gold mineralization in the Kaczawa Mountains, Western Sudetes. Polish Geological Institute Special Papers, 22: 1-162.

Mikulski, S.Z., Speczik, S., 2008. Organic and inorganic geochemistry of gold mineralization at the Zloty Stok, SW Poland. Applied Earth Science, 117:149-159.

Mikulski, S.Z., Williams, I.S., Bagiński, B., 2013. Early Carboniferous (Visean) emplacement of the collisional Kłodzko-Złoty Stok granitoids (Sudetes, SW Poland): constraints from geochemical data and zircon U-Pb ages. International Journal of Earth Sciences, 102: 1007-1027.

Oberc, J., 1957. Region Gór Bardzkich (Sudety). Przewodnik dla geologów. Wyd. Geol., Warszawa.

Oberc, J., 1972. Sudety i obszary przyległe. Budowa Geologiczna Polski. Tom 4, Tektonika część 2. Wyd. Geol., Warszawa.

Oberc, J., Badura, J., Przybylski, B., Jamrozik, L., 1994. Szczegółowa mapa geologiczna Sudetów w skali 1:25 000, arkusz Bardo Śląskie. Państwowy Instytut Geologiczny, Warszawa

Pearce, J.A., Harris, N.B., Tindle, A.G., 1984. Trace element discrimination diagrams for the tectonic interpretation of granitic rocks. Journal of Petrology, 25: 956-983.

Pendias, H., Maciejewski, S., 1959. Zbiór analiz chemicznych skał magmowych i metamorficznych Dolnego Śląska. Prace Instytutu Geologicznego, 24: 1-133.

Roche, H., de la, Leterrier, J., Grandclaude, P., Marchal, M., 1980. A classification of volcanic and plutonic rocks using $\mathrm{R} 1, \mathrm{R} 2$-diagrams and major element analysis - its relationships with current nomenclature. Chemical Geology, 29: 183-210. 
Sawicki, L., 1980. Mapa Geologiczna Polski. B - Mapa bez utworów czwartorzędowych. 1:200 000. Wyd. Geol., Warszawa.

Turnau, E., Żelaźniewicz, A., Franke, W., 2002. Middle to early late Viséan onset of late orogenic sedimentation in the Intra-Sudetic basin, West Sudetes: miospore evidence and tectonic implication. Geologia Sudetica, 34: 9-16.

White, A.J.R., Chappell, B.W., 1977. Ultrametamorphism and granitoid genesis. Tectonophysics, 43: 7-22.

Wierzchołowski, B., 1969. Granitoids of Bardo in Sudetes (in Polish with English summary). Archiwum Mineralogiczne, 28: 107-132.

Wierzchołowski, B., 1976. Granitoids of the Kłodzko-Złoty Stok massif and their contact influence on the country rocks (petrographic characteristics) (in Polish with English summary). Geologia Sudetica, 11: 3-143.

Wierzchołowski, B., 1977. Dike rocks of the Kłodzko-Złoty Stok granitoid massif (in Polish with English summary). Geologia Sudetica, 12: 7-28.
Wierzchołowski, B., 2003. Potassium-rich dyke rock of Rogówek. Archiwum Mineralogiczne, 54: 7-97.

Williams, I.S., 1998. U-Th-Pb Geochronology by Ion Microprobe. Reviews in Economic Geology, 7: 1-35.

Williams, I.S., Claesson, S., 1987. Isotopic evidence for the Precambrian provenance and Caledonian metamorphism of high grade paragneisses from the Seve Nappes, Scandinavian Caledonides. II. Ion microprobe zircon U-Th-Pb. Contributions to Mineral Petrology, 97: 205-217.

Williams, I.S., Hergt, J.M., 2001. U-Pb dating of Tasmanian dolerites: a cautionary tale of SHRIMP analysis of high-U zircon. In: Beyond 2000: New Frontiers in Isotope Geoscience (eds. J.D. Woodhead, J.M. Hergt and W.P. Noble): 185-188. University of Melbourne, Melbourne.

Wojciechowska, I., 1975. Tectonics of the Kłodzko-Złoty Stok granitoides massif and its country rocks in the light of the mesostructural investigation (in Polish with English summary). Geologia Sudetica, 10: 61-121. 